Florida International University

FIU Digital Commons

FIU Electronic Theses and Dissertations

University Graduate School

$2-1984$

\title{
A study to determine and analyze the attitude of restaurant operators in Miami Beach toward the use of credit cards at their establishment
}

Yair Eldar

Florida International University

DOI: $10.25148 /$ etd.FI15101285

Follow this and additional works at: https://digitalcommons.fiu.edu/etd

Part of the Food and Beverage Management Commons

\section{Recommended Citation}

Eldar, Yair, "A study to determine and analyze the attitude of restaurant operators in Miami Beach toward the use of credit cards at their establishment" (1984). FIU Electronic Theses and Dissertations. 3133.

https://digitalcommons.fiu.edu/etd/3133

This work is brought to you for free and open access by the University Graduate School at FIU Digital Commons. It has been accepted for inclusion in FIU Electronic Theses and Dissertations by an authorized administrator of FIU Digital Commons. For more information, please contact dcc@fiu.edu. 
A STUTY TO DETERMINE AND

ANALYZE THE ATTITUDE OF

RESTAIRANT OPERATORS IN MIAMI

BEACH TOWARD THE USE OF CREDIT

CARIS AT THEIR ESTABLISHMENT

by

Yair Eldar

A Hospitality Froject Submitted

in Partial Fulfillment of the

Requirements for the Depree

MASTER OF SCIFNCE

in

HOSPITALITY MANAGEMENT

at

FLOR IDA INTF,RNA TIONAL UNIVERS ITY 
To Professor Steven Moll and Professor Alan Parker

This hospitality project is beinf referred to you for judgment upon its substantial merit.

Dean Anthony $G$. Marshall

School of Hospitality Management

The hospitality project of Yair Eldar is approved.

Professor Steven Moll

Professor Alan Parker

Date of examination: February 1984 
TABLE OF CONTENTS

Section

Page

THE PROBLEM AND ITS SETTING .....

The Statement of the Problem. . .

The Subproblems ..........

The Hypotheses...........

The Delimitations . . . . . . .

The Definition of Terms ......

The Assumptions . . . . . . . .

The Importance of the Study . . .

Credit.

Credit Card History . . . . . 10

Bank Credit Cards . . . . . . 17

One Company Cards ....... 20

Travel and Entertainment Cards... 22

Advantages and Disadvantages for the

Merchant......... 24

Cash Discounts :. . . . 28

The Hospitality Industry and the

Credit Cards
Hotels and Credit Cards: : : : :

Restaurant and Credit Cards.....

The Data. Criteria for Admissibility of the

Data. . . . .......

The Research Methodology. ....

Specific Treatment of the Data for

Each Subproblem .........

THE INTERPRETATION OF THE SURVEY FINDINGS

AND RECOMMENDATIONS ....... 59

VII CONCLUSION。................ 68 
SECTION I

THE PROBLEM AND ITS SETTING 


\section{THE PROBIEM AND ITS SETTING}

The Statement of the Problem

The purpose of this study is to determine and analyze the attitude of restaurant operators in Miami Beach toward the use of credit cards at their establishment. The Subproblems

1. The first subproblem. The first subproblem is to determine the attitude of restaurant operators toward the use of credit cards at their establishment.

2. The second subproblem. The second subproblem is to analyze operators attitudes towards the use of credit cards at their establishment.

The Hypotheses

The first hypothesis is that restaurant operators dof't like the use of credit cards at their establishments, especially the travel and entertainment credit cards.

The second hypothesis is that restaurant operators dox't like the use of credit cards because of the cards negative effect on their business cash flow and profits. The Delimitations

This study will be limited to freestanding restaurants In the city of Miami Beach which have 100 seats or more. The study will include only restaurants that accept Bank and Entertainment credit cards at their establishments. The study will check attitudes towards the following 
credit cards: VISA, Master Card, American Express, Diner's Club, and Carte Blanche.

The Definition of Terms.

Credit Card. A card authorizing purchase on credit. When a purchase is made the card is presented and identifying figures and name are taken from it in order to bill the customer in a later date.

Bank Credit Card. Two credit card operations run by VISA and Master Card.

Different financial institutions (Banks, Savings and Loan Companies, Real Estate Companies, etc.) are franchisees of the two card companies. These financial companies issue cards, collect and make payment under the bank card companies.

Travel and Entertainment Credit Cards. Credit card carrying the name American Express, Diner's Club and Carte Blanche.

In the past they were used mostiy in travel and entertainment facilities. Hence, their name. The name remains today primarily to distinguish them from bank cards.

One Compeny Credit Card. A credit card which is issued by a particular company to be used for purchasing the products or services of this company.

Hospitality Industry. In this study the Hospitality Industry is being referred to the Hotel and Restaurant business. Assumptions

The first assumption. The first assumption is that the 
operators attitudes toward the use of credit cards at their establishment $w 11$ be determined by the amount of credit card charges and their ratio to total sales.

The second assumption. The second assumption is the time for restaurant operators to collect the credit card charges is a major consideration in restaurant operators attitudes toward the use of credit cards at their establishment.

The Importance of the Study

The restaurant business is dependent upon its ability to attract customers and thereby finance its continuous operation. The credit card. Which plays an important role in the financial management of the modern man, has influenced the restaurant business since it became acceptable as a method of payment in the hospitality industry.

On one hand, the ability to pay with credit cards attracts people who are so accustomed to using them that they seldom carry cash. These people might not be customers if they were not allowed the option of paying with a credit card at a particular establishment, and would more than likely choose to dine at a restaurant which accepted this form of payment.

on the other hand, the payback period of some credit card companies is as long as one to two weeks and this has serious negative effects on a businesses cash flow. This may result in a lessening of the establishments purchasing 
power and/or its ability to make physical and operational improvements in the short run.

The magnitude of credit card use has made it a phenomenon that the restaurant business cannot ignore. The individual restaurant operator must carefully weigh the advantages and disadvantages when deciding whether or not to accept credit cards, and which ones, at his place of business. For this reason this research may be of particular interest and most beneficial to him. The survey results will show if owners of already established restaurant operations are in favor or opposed to credit card use, and if they are opposed, why? Therefore, reading this research may assist new operator in making his decision regarding the acceptance of credit cards at his soon-to-be restaurant.

By shedding some light on problematic areas associated with credit card use, the results of the survey will indicate that some solutions or alternatives to the present system may surface. This should be of importance to the major card companies and also to restaurant industry associations, who as a collective unit may influence the card companies system, or at least educate their members as to ways to work with the credit card system as it now exists.

Of course, individual owners and managers should take the inttiative to constantly inform themselves on the issues which are pertinent to their business. The high failure rate of restaurants may be somewhat attributed to the fact that 
many owners and managers don't "do their homework" and give attention to a situation only after it has become a near crisis. Problems with credit acceptance alone will not be the downfall of any restaurant, but they will affect the overall financial picture, particularly the cash flow and profit. Since this is the case, this research should be of interest to anyone who sees the importance of being informed on the issues that affect their business and values awareness and knowledge as means of safeguarding their assets. 
SECTION II

THE RELATED LITERATURE 


\section{THE REVIEW \\ OF THE RELATED LITERATURE}

Credit

Meaning: The word credit is derived from the Latin word credere - to believe.

Credit is believability. credibility. The customer makes a promise to apy and the merchant believes the promise. 1

Knight and Crowell in their Dun and Bradstreet Handbook of Credit and Collection define credit as:

The power to promise future
consideration in the form of
goods, services, cash or
another economic value for
the present acquisition of
goods, services, cash or
another economic value.

History

Credit precedes coining by over two thousand years. In prehistoric times, even before the development of a common measure of value or of a medium of exchange, credit

1J. Seder. Credit and collection, p. 11.

2Knight and Crowe11. The Dun and Bradstreet Handbook of Credit and collection, p. 1 . 
probably existed. It might have started with the loan of apriculture products (significant to these times) such as seeds or animals, which were returned in the form of harvest, plus interest. 3

The oldest credit structure preceding coining is dated to 3000 B.C., according to sumerian documents. At this time the use of credit was based on loans of grain by volume and loans of metal by weight. 4

The recorded legal history of several great civilizations started with the formulation of laws governing credit. The Hammurabl Code of Law 1800 B.C., is the earliest known formal code of law for Ancient Babylonia. It deals primarily with the regulation of the relationship between debtor and creditor.

Great nations like Greece and Rome, began their legal history with a body of laws regulating credit. These laws came about because of a crisis in the existing society, characterized by excessive debt, which caused slavery and poverty.

The Babylonians and Assyrians were lending money on the basis of mortgages, advance deposits, and other security

$$
\begin{aligned}
& \text { 3H. Sidney, A History of Interest Rates, p. } 18 . \\
& \text { 4Ibid., p. } 17 . \\
& \text { 5Ibid., p. } 5 .
\end{aligned}
$$


Instruments.

In Babylonis, approximately 1000 B.C., unsophisticated bi11s of exchange were introduced.

The Roman's time represents the extension of credit throughout the empire. During this period documents had reached high levels of development and sophistication.

The collapse of the Roman Empire signaled the coming of the Middle Ages. Credit was still a major factor in trade between all cities in Christendom and was carried out on the basis of letters of credit.

The expanded use of credit between Italian bankers facilitated the redevelopment of production and consumption that grew into the Renaissance.

Once the new world was discovered mercantile credit experienced even preater growth.

Even thouph Europe's money supply increased with the import of newly discovered precious metals, trade between European colonies and their mother countries continued to be financed through credit.

B111s of Exchange and promissory notes, which were often endorsed, not only traveled between England and the colonies, but from one colony to another to finance trade. The borrowing terms were usually twelve months or longer. By the $1850^{\prime}$ 's the credit period had been reduced to four to eight months, and more American manufactured goods were introduced into the trading picture. 
Promissory notes remained common and trade acceptances came into general use. Merchants began to offer cash discounts of 5-30 percent.

The Civil War caused significant changes in credit prectices in the United States.

The growth of commercial banking had facilitated the use of credit, but now money was untrustworthy and merchants wanted fast payment. Terms fell to thirty to sixty days and cash discounts became a popular way to induce quick collection of receivables.

The fast paced transaction of this period contributed to the development of open book account terms. Credit terms never came back to their previous long term arrangements after the Civil War. In fact, as customer buying pace increased, shorter terms became even more common. Developments in transportation and communication also contributed to the shorter term arrangement of credit, which became the predominant form of trade credit. During this period cash discounts were also substantially reduced. 6

By the second half of the 20th Century, we had become a society in which credit is a basic and vital element of existence. Credit is noticed everywhere, beginning with the credit given by the telephone, gas, and electric companies to their customers. Credit Bureaus have been created to check

6Knight and Crowe11. The Dun and Bradstreet Handbook of Credit and collection, $\mathrm{pp} .3-4$. 
credibility of customers.

The check book, which represents the dollar amount a person is supposed to have in the bank, became the basic and most important way to pay for goods or services. Problems which have arisen with the practice of checking (forging, unreliable source of money, excessive paper work) have opened the door for the credit card and moved us one step closer to the cashless society.

\section{Credit Cards}

The word credit card was first applied by Mr. Edward Bellamy, a lawyer and journalist in 1887, in his best seller Looking Backward 2000-1887, which describes the American society in the year 2000 .

In his book, Mr. Bellamy describes the cashless soclety of the year 2000, in which a person who falls asleep in 1887 is awakened in a society where the credit card is one of the major factors for existence.?

Today both critics and supporters of the credit card agree it is a major factor contributing to the cashless society of the future. A society in which the credit card is definitely a sign of the times.

\section{History}

The use of credit cards in the United States dates

7Robert Henarickson, The Cashless Society, p. 47. 
beck to the first World War. Crecit cards were issued then by a small number of hotels, ofl companies, and department stores.

The cards had several purposes--to identify a customer with a charge account, to keep a record of customer purchases, and to attract customers to the store by giving them a feeling of identification.

The growth of credit cards was halted by the Depression. During the second World War most firms did not use their credit caris because of the war time credit restriction. ${ }^{8}$

Credit cards grew to their present popularity primarily because of one man-Frank $X$. McNamara. Mr. McNamara was an ingenious entrepreneur who decided that credit cards would be more useful if they could be used at more than one place. His initial interest was in those persons who ate at many restaurants and would find value in a card that would be honored at many of these establishments.

Out of his plan grew the Diner's Club credit card operation, which he and partners owned for a short while until losses brought on his retirement.

The original Diner's Club was operated as follows:

The credit card company would bill card holders once a month and pay the charges to the restaurants less a discount for the collection 
service. The cardholder

in turn presumably gener-

ates enough business to
justify the discount.

Diner's Club, the first of the so called travel and entertainment cards, was later joined by American Express and Carte Blanche.

The travel and entertainment cards were directed towards the reasonable, well heeled businessman on the move. They stressed restaurants, hotels, and travel coverage in the United states and abroad. Their profits came from a fee paid by the cardholder and a discount rate paid by the merchant for every credit card payment in his store.

The importance of Mr. McNamara's idea was that for the first time a person could charge in different places for different kinds of goods and services using the same card.

The next and maybe the most important stage in the existence and development of credit cards was the entrance of banks to the credit card field. The first bank to enter was Franklin National Bank of New York, which developed its credit card plan in 1951. By 1955 the number of banks operating their own credit cards plans had grown to more than one hundred.

At the beginning the bank cards in contrast to the travel and entertainment cards, which were launched nationally, were Iimited to a bank's geographic area, meaning the state 
or clty in which the bank was located. 10

The second stage in the growth of bank cards came in 1958-59, when a number of the larger banks including Bank of America, Chase Manhatten, and Marine Midland Trust introduced charge and card plans.

The card was viewed during this time as a new customer service rather than a revolutionary change in payment method. 11

In the beginning the bank card plans, in contrast to the travel and entertainment cards, of not charge fees from card holders and the bank card companies income was derived from the discount rate charged to the unpaid balance of the card holders.

The banks treated the credit card as another tool to ensure revolving bank credit, which was in fact, a short term loan at high interest rates, 18-20 percent a year.

Banks, while trying to get customers, were mailing unsolicited credit cards to those meeting such minimal credit standards as being listed in the telephone book or having any kind of account in these banks.

The solicitation was done in order to add new merchants to their list of accounts by impressing them with the large number of potential card holding customers.

10Imin Ross, The Credit Card's Painful Coming of Age, October 1971, p. 109.

11Thomas Russe11, The Economic of Bank Credit Cards, p. 4 . 
The uncontrolled solicitation caused fraud and failure of unreliable customers to pay their bills. This resulted in some bank operations losing money and endangering their local card operations. Another important factor which limited bank card operations, especially in the East Coast, was the absence by law of branch banking. This severely restricted the geographic area over which the card could be used.

By 1965 some bif banks like Chase Manhatten were out of the card game.

In 1966 Bank of America with its branches all over California, decided to launch its Bankamericard Service Corporation and to license its scheme to other banks, which paid a fee to join the system.

This still gave Bank of America the control of the entire operation, while obtaining increased revenues. However, now they had to share these revenues with banks which had joined the system.

Other bif banks, especially in the East Coast who did not like the tight controls of Bank of America, formed a non-profit orgenization called Interbank, which began running its card under the name of Master Charge. Such advantages of joining one of these two organizations--as a larger base of merchants, less risks by the single bank enjoying the experlence of the big companies-were realized very quickly by most local banks in the United States.

Many banks quit their own card programs and joined 
one of the two large organizations.

In 1977 Bankamericard gave the name VISA to its credit card and tried to establish itself as an international card, or as De.W. Hock, VISA president claimed, "To offer a name that has world wide identity and is free of adverse regional and political implications." 12

Immediately afterwards Master Charge changed its name to Master Card in order to get away from the charge symbol and meaning.

These two large companies have also established themselves as international companies.

VISA claims to have between 70-80 million card holders around the world, while Master Card is slightly behind with close to 70 million card holders.

One of the major problems facing the credit card companies and merchants accepting, these cards from their origins until today is fraud.

The card companies battle this problem with weekly bulletins that specify bad cards, and require the merchant not to accept them. Another precautionary measure is the telephone authorization of the credit card.

The latest and newest idea which is still in the beginning stages is a credit card with a magnetic strip which when read by a special device, can help insure the merchant and the bank apainst fraud. Its development started

12 "Credit Card War Moves into High Gear," U.S. NewS \& World Report, March 5, 1973, p. 73. 
in Europe but is being delayed in the United States because of its high cost.

Card companies 1 ike VISA began installing POS (point of sale) terminals in some of the bigger stores.

The POS system works like this: when a customer uses his credit card to make a purchase, the card's magnetic strip will be read by the POS terminal, which will verify identification and will immediately transmit the data to one of the participating banks. The computer in the bank will than communicate with one of VISA's computers, which will check whether or not the account is in good standing, and transmit this message to the merchant. Finally, if the account is good the bank will add the purchased amount to the customer's outstanding balance.

This system is useful because of its reliability and quickness. 13

One of the main problems which faced the credit card companies was the resistence of major retail stores like Sears and J.C. Penney to honor their cards.

Recently these companies have begun to see the major credit cards as something other than competitors with their own credit system.

They have been trying the bank cards for the last year and $J . C$. Penney has already a greed to accept it in all

13Bob Johnson, "VISA Installing System to Combat Fraud," Computer World, September 7. 1981, p. 19. 
their stores. 14

It seems that pretty soon the credit card is golng to be acceptable almost everywhere. The credit card is seen by many experts as mover from point $C$ (checking) to point $E$ (electronic), or as the American Association has claimed, "The bank credit card will one day lead to the checkless cashless society." 15

Credit cards are making the way for widespread point of sales. They allow the bank and the merchant to minimize the paper work and delays that are still characteristic of the checking period.

Bank Cards

Bank cards today are composed of two major companies-VISA and Master Card, with franchises all over the United States.

Master Card belongs to Interbank, a non-profit organization whose 9700 bank members in the United States share operating cost and revenues.

VISA is a for profit group owned by some 10,000 issuing banks. The banks share is in proportion to the value of their card sales.

Both groups derive their funds from schedules of membership fees, dues, and assessments and operate their own

14 "Bank Credit Cards Setting the Scene for Future POS," Saving \& Loan News, August 1979, p. 96.

15 "ABA Calls Bank Credit Card Key to Less Check Future," Management Services, March-April 1968, p. 6. 
communication network for authorizing credit purchases at the point of sale. ${ }^{16}$ Due to the vast area of operetion and the different banks involved, VISA and Master Card are seen as an umbrella organization which includes card issuers, egent banks, and merchant banks.

A card issuer is a financial institution that approves a customer's application, issues the credit card, and funds the customer's loan balance.

An agent bank is a financial institution that solicits its customers to apply for credit cards; actually issued by a card issuer for which the institution is an agent.

The agent bank compensation ranges from a finder's fee to participation in the funding and the profit or losses on the actual account.

A merchant bank is a financial institution which signs up merchants to accept the card. It accepts the merchant's credit card sales charges and clears them through the bank card system.

When a customer is making a purchase the merchant calls the authorization center which has the record of the card holder's accounts and the issuer's bank.

When the purchase is being authorlzed the merchant sends the credit slips to its merchant bank and promptly gets back the sales, less the discount rate. The merchant bank in turn seeks payment from the issuer bank where the customer p. 95 .

16" clash of the Credit Cards," Dun's Revlew, June 1978, 
has his account, and usually it will get the money less an interchange fee which has been deducted by the issuer bank. 17

Bank cards from the start set limits on how much the individual card holders could spend over a period of time. At the beginning, bank cards were not only free, but for a long while were forced upon people by the companies in an effort to increase the base of their card members. In the fifties they used to send applications and cards to anyone who had any kind of account in a bank.

By 1980 under President Carter's credit control policles, banks were encouraged to start levying annual fees or other charges for the cards. 18

Bank credit card fees today are between 15-25 dollars depending upon the bank and the state where the card is issued. 19

Banks are encouraging their customers not to pay all of their bills once a month, but to extend payment over a longer period of time so the bank can profit from the accrued interest. This interest is a primery source of income in the credit card scheme.

17Walter Klechel, III, "Explosion in the Bank Card Cafeteria," Fortune, September 8, 1980, p. 77.

18 Terry Galanoy, Charge It-Inside the credit card Conspiracy, $p .21$.

19Robert Stickler, "Banks Wrapping their Customers in Colored Plastic," Miami Herald, September 5, 1983, p. 24. 
Both bank cards offer their card holders guaranteed hotel reservations.

In the last few years the bank cards have begun to approach the upscale business market, which was ignored by them in the past, and was approached only by the travel and entertainment carss.

Both companies, VISA and Master Card, have realized the potential in the upscale market and have issued a premium card which offers more privileges to its holders. The new card's features are: a minimum spending limit of $\$ 5000$ dollars, cash advances, and check cashing at participating banks and certain hotels and airlines, as well as travel insurance of at least $\$ 150,000$ dollars and supplemental insurance for air travel of up to $\$ 250,000$ dollars. 20

One Company card

The one company credit card was the only card at the scene in the beginning of the century. They were issued in very small numbers and. were given to chosen customers of oil companies, department stores, and hotels.

Their issuance was accelerated following the second World War, when they were given to customers for purposes of identification, record keeping, or as Irwin Ross claims in his article, "The Credit Cards Painful Coming of Age,":

The oil companies

and department stores use

$20 "$ Master Card and VISA A Ir Their Differences in Friendly Fashion," ABA Banking Journal, November 1981, p. 113. 


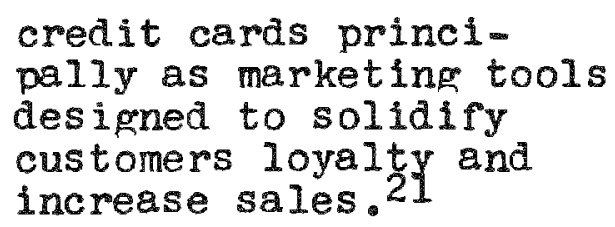

Today the two largest fields in which credit cards are issued are the oll companies and the large department stores. In fact, in 1978 Sears and J.C. Penney had more card members than all the bank and travel and entertalnment card companies together.

Some of the one company credit cards have grace periods in which several weeks free credit are given to users who pay their credit card bills when they are due. When the bill is not paid on time, the customer must pay a finance charge. 22

In the past five years there has been strong battles between the benk credit card companies and the big department stores. The banks which tried to enter the department store scene encountered a lot of difficulties from J.C. Penney and Sears. These companies, were afraid that the bank cards might cause their customers to identify less with their particular stores and consequently, reduce their sales. Eventualiy these retailers were forced to accept the fect that the bank cards were here to stay and they began accepting bank cards. The end result might be a reduction in store credit cards in the future. 23

2IIrwin Ross" "The Credit Card's Painful Coming of Age," Fortune, October 4, 1971, p. 109.

22 Lewis Mande1I, Credit Cards in the U.S., pp. 4-5. ait Cards Setting the Scene for Future Pos," lews, A ugust 1979, pp.96-9?. 
The other major one compeny credit cards are the oil companies which have recently realized the negative effect of credit card sales on their cash flows, and are now encouraging their customers to pay cash by offering cash discounts at the gas pump.

Many of these companies are turning their recelvables over to other companies in order to eliminate the expensive cost of collecting the money owed to them by their customers. Some of the one company credit cards, such as the oil companies, allow their card holders to charge purchases in hotels or restaurants with their card according to previous arrangements by these companies.

Travel and Entertainment Cards

There are three major national travel and entertainment credit cards: American Express, Diner's Club, and Carte Blanche. These cards are called Travel and Entertainment Cards in order to distinguish them from the Bank Cards. The name Travel and Entertainment was more appropriate in the past than presently.

In the past, these cards have been oriented almost exclusively to restaurants, hotels, and transportation companies. They have offered a fairly narrow range of services and products over a limited geographic scope. Today the travel and entertainment credit cards are wide spread and offer a variety of services almost everywhere, and in every type of business. 
From the beginning the travel and entertainment credit cards have approached the higher income persons, particularly businessmen. They are popular among this group because of such features as the unlimited amount of money that can be spent with the cards, the accidental death and dismemberment insurance coverage on air or sea travel for the card member or his family, a check cashing guarantee up to $\$ 250$ dollars at most hotels and motels in the United States and Canada, and up to $\$ 50$ dollars at participating car rental and U.S. airlines counters.

The card holder can make a reservation for many hotels in the United States and have the room guaranteed and waiting for him until the next day.

The travel and entertainment card companies charge annual fees between $\$ 40-\$ 50$ dollars depending on the kind of card the customer carries (gold or regular). 24

The travel and entertainment credit card companies income is derived from the discount rate charged+to the merchant and the annual fee the card member must pay.

The discount rate depends upon the volume of the merchants sales, and his agreement with the card company.

The average discount rate is 3-7 percent, however, it can go as high as 10 percent of total card sales.

Usually, the travel and entertainment card companies will refund the credit card charges to the merchant within 
3-7 days from the time of purchase.

An express delivery which means a shorter delivery time will hike the merchant's discount rate.

The travel and entertainment card companies guarantee the merchant the amount of the purchases as long as the merchant has obtained authorization from the company, even if the customer disputes the charges. 25

The travel and entertainment card companies require their card members to pay their debts once a month. Seldom do they agree to extended payment plans with added rinance charges.

Some companies like American Express provide the card holder with a convenient "country club" slip. This is a copy of each charge and is remitted along with the total bill. This is especially useful to businessmen when accounting for taxes. 26

The three travel and entertainment credit card companies have about 15 million card members around the world. American Express is the most active and has close to 12 million card holders; Diner's Club has 2 million card holders, and Carte Blanche has 1 million card holders.

Advantages and Disadvantages for the Merchant

The credit card represents both problems and advan-

$25 \mathrm{John}$ Seder, Credit and Collectlon, pp. 53-54. 26 Walter Kiechel III, "Explosion in the Bank Cand Cafeteria," Fortune. September 8, 1980, p. 78. 
tages to the merchant in regards to the every day operation of his business.

\section{Advantages}

Merchants in different areas used to extend credit to some of their customers after verification of their credibility. The credit card eliminates the time and effort spent by the merchant to establish the credit approval of each of his customers. 27

Many customers prefer using a credit card to writing checks and this may decrease the owners chances of accepting bad checks. Also, as a result of the credit card popularity, many businesses no longer accept checks at all.

The travel and entertainment companies guarantee checks for their card holders up to $\$ 250$ dollars.

The merchant is assured that as long as he gets authorization for the check from the credit cand company he will get his money, even if the check bounces. 28

The use of credit cards reduces the amount of cash which a merchant receives and evidence indicates that the decreases the temptation to steal and the potential loss through robbery.

The credit card can attract new customers to a

27 John Seder, Credit Card and Collection, p. 59. 28 Thomas Russel, The Economic of Bank Credit, p. 84. 
business. Some will come and buy at a particular establishment because it accepts credit cards and its competitors do not.

Others will make unplanned purchases simply because of the ease of buying with a credit card.

Many people, particularly traveling businessmen, do not like to carry cash and the only way to capture the business of this group is to accept credit cards.

Martin J. Meger, president of National Desposition Corporation Association in New York, in a somewhat bitter argument against the credit cards, said:

Credit cards used to be a selling gimmick. They were a selling arm of the finer restaurants and hotels. Today it has become necessary for every place to honor them... and so there is no longer a selling advantage to having them, just a selling disadvangage to not having them.29

Some researches have shown that credit card customers are bigger spenders than cash customers, and for this reason stores which accept credit cards show higher sales than similar stores that do not. 30

The travel and entertainment card companies will pay the merchant the charge amount, even if the customer disputes the charges.

$$
\begin{aligned}
& 29 \text { Ibid, p. } 30 . \\
& 30 \text { Ibid., p. } 31 .
\end{aligned}
$$


They will settle the dispute with the customer without involving the merchant. This allows the merchant to deal with his regular business instead of trying to collect money from customers who refuse to pay.

\section{Disadvantages}

The merchant has to pay the card companies a discount rate which ranges from 1-9 percent of each credit card sale.

The smaller the volume of sales the higher the discount rate.

The discount rate might cause the merchant to increase his prices in order to pass the expense on to the customer. If the merchant decides to let his prices stay the same, his profit will decline.

The discount rate is applied to the total amount of sales per check, including tips and taxes. A merchant with a high volume of credit card sales might find himself paying a discount for his employees tips and for the state taxes. The merchant is required by the card companies to check clients signatures and get their authorization for the sale; if the merchant is negligent in getting authorization and either obtains a fraudulent signature or accepts charges above a customer limit he must carry the loss.

Department stores, unless they are very careful, tend to lose track of their regular customers and lose the opportunity to send them promotional literature and announcements of sales. 
The bank card companies reimburse the merchant for his charge sales the day after they are deposited in the bank.

The travel and entertainment card companies will pay the money 3-7 days (and sometimes even longer) after the charges were incurred.

This can effect the cash flow of individual businesses, especially if the volume of travel and entertainment credit card is high, and the merchant is in a business where he needs cash to pay for his every day expenses.

The expenses of the printing machine, paper supply, and postage have to be added to the total merchants expenses of doing business with the credit cards. 31

Cash Discount

As soon as merchants had realized the extra expenses and burden, credit cards can cause their businessethe question of discounts for cash arose. Charging, Time Magazine claims:

Credit card trans-

actions cost merchants money which they recover by charging higher prices for the goods they sell. These prices are peid not only by charge cus tomers who keep the benefits of credit cards, but also by cash customers who don't. As a result, those who pay cash are subsidizing their card carrying counterparts, so

${ }^{31}$ John W. Seder, Credit Card and Collection, pp. 60-63. 
it seems perfectly

logical and fair that

cash customers will

be given discounts on

the goods they buy. 32

Credit card companies usually have included a clause in their contract with the merchant which restricts the merchants from giving discounts to cash paying customers.

The Congress which prohibited that practice specified that discounts of up to five percent for cash paying customers provided they were disclosed and affected to all customers, would not be considered a finance charge for the merchant, and thus open the door for a limited cash discount.

Although stores are permitted to give discounts to cash paying customers they are prohibited from imposing a surcharge on credit buyers. 33

With few exceptions the movement for cash discounts never really got off the ground.

Bichard Peterson, senior Research Scholar at Purdue University Credit Research Center Claims:

The law itself is the

blame. By allowing alscounts but prohibiting a surcharge on credit cards the argument goes. Congress deprived merchants of the more attractive of the two options... consumer groups opposed it because they didn't believe markets would compete by charging lower prices for cash, 


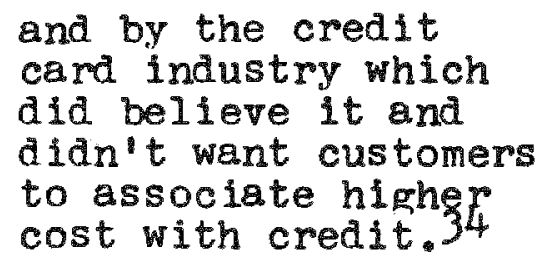

The merchants view the discount for cash with a careful eye.

The discount for cash might play havoc with the merchant pricing structure and end up costing him money.

Proponents of cash discounts usually propose that the discount will be equal to the service fee the merchant would otherwise pay the bank for a credit sale.

However, it doesn't necessarily follow that the price of each item sold include the exact discount rate being charged by the care companies. Businesses often considered the cost of credit cards as part of their overhead to be paid out of the profit margin.

If the merchant will give the customer a lower percentage discount for cash, the latter might feel he is being cheated. And, if the cash discount will be exactly as the discount rate, the merchant may find himself losing money. Merchants also fear that cash customers will continue to pay cash and get the cash discount, while credit customers will continue to prefer the convenience of plastic. The business would then have the same credit costs but fewer profits. 35 Another potential deterrent to cash discount is that 
merchants, especially in small towns, may want to continue giving banks as much credit card business as they can, based on their financial and moral obligations to help the banks that have helped them with mortpage and inventory financing.

Supporters of cash discounts are using an argument created by the credit card companies for their own advertisement. Curtis Prins, Staff Director of the U.S. House of Representative Consumer Affairs Subcommittee says:

We are not asking merchants to do customers any favors. We are asking them to use cash discounts as a marketing tool to bring more people into their stores. You might lose a few pennies on one sele, but if the customer hadn't come in, in the first place, you would have lost the whole sale. 36

The merchants clams against it, is that the cash discount they offer is so low that it doesn't give customers much incentive to take advantage of it. Robert Gibson, President of the National Foundation for Consumer Credit, says:

People are reluctant to hassle; they want to avoid personal confrontation and that's why you would expect the idea of discount for cash to be very attractive, but under used. 37

A National Restaurant Association executive sald that the discount rate would be determined by the individual restaurant.

37 Ibid., p. 58 . 38Ibld. p. 59. 
He said, however, that credit cards are reflected in menu prices only to the extent they represent part of the cost of doing business. Therefore, customers cannot automatically assume that they are entitled to a discount comparable to the percentage charged by an operator as a service fee. 38

Until today, only one major industry has used the cash discounts on a large scale. The oil industry uses the cash discounts to minimize the high cost of credit card use, caused by the difficulties of collecting vredit card receivables.

The cash discount for cash paying customers has caused some companies to experience growth in their sales volume. Allen and Kelly, an Exxon outlet in Bryn Mawr, Pennsylvania, says:

Volume has risen 15 percent since we started charging cash customers four cents a galion less 39

Others claim that the discount has spread to so many brands of pasoline it no longer gives any one an edge and now reduces dealer's profits.

Many dealers detest the extra bookkeeping necessitated by the two price system and fear that they will allenste regular credit card users. 40

38"Few Discounts for Cash Seen Despite Ruling, "Advertising Age, April 22, 1974, p. 2.

390 is count for Cash,"wall street Journal, Sept. 30, 1982, p.1. $40 I$ bid. 
It seems that the cash discounts in the gas stations are not very profitable because most companies are using them as a must to be competitive in the market.

The only cash discount programs that appear to have the potential to expand nationwide is Saving plus, which has started in Sikeston, Missouri.

Saving plus franchises have already been established in North Dakota, Iowa, New Mexico, Louisiana and Arkansas, among other states.

The program includes thousands of participating merchants and customers. The program works like this: the customer opens a savings account with the sponsoring bank in his area. (A minimum deposit is required). The customer is given a list of participating merchants.

When a customer makes a cash purchase from one of these merchants he pays full price. A portion of the payment is deducted by the merchant and deposited into the customer's savings account, by the tenth of the following month. The customer is entitled to discounts averaging 7 percent from the saving plus merchants.

Saving plus has been given a better chance of succeeding than other cash discount plans because of its ties with financial institutions, which have an interest in publicizing the program to attract new deposits. Saving plus promors are tooting the program as a marketing tool that w11 give merchants a competitive edge, improve their 
cash flow and build customers loyalty. ${ }^{4 I}$

The Hospitality Industry and the credit card

The hospitality industry defined in this study to be the hotel and restaurant business has been highly influeneed. and effected by the credit card phenomena.

Hotels and Credit Cards

Credit cards and hotels have been connected since the beginning of the credit card. Hotel credit cards were among the first one company credit cards which started the credit card movement.

Hotel credit cards were introduced as a marketing tool and were given to reputable and frequent customers.

Their purpose was to encourage patronage and repeat business by the card holders.

The hotel credit card has never become a mass movement, and is now used only for advertisements in certain circles, particularly geared toward businessmen.

Those credit cards which are seen today have become scarce, due to difficulties of collecting the receivables and the introduction of the travel and entertainment, and bank credit cards.

The major credit card companies have changed the way hotels do business.

A research study by the credit card companies which appeared in Lodging and Hospitality indicated that for many 4I"Whatever Happened to Discounts for Cash?", Changing Times, May 1980, p. 59. 
travelers acceptance of a specific card by a lodging facility is an important factor in deciding where to stay. It became such as important issue that the American Hotel and Motel Association Red Book and other travel guides include credit card data in their listing of properties. 42

The use and acceptance of a credit card guarantees the lodging operator a full payment by the credit card company.

Because of the large number of bad checks $(300,000$ bad checks a day is the figure published by the Rederal Reserve Board) many lodging operators now refuse to accept any personnel checks.

American Express, in a survey of its card holders, learned that the no check policy in force at many hotels was of major concern to them. The inability to get cash in a strange city has worried many travelers. As a result, American Express has agreed to back up card members checks in order to protect operators from being stung and increase their service to their card holders.

This program was followed by the two other trevel and entertainment card companies and the bank card companies for their premium card holders. 43

In the past, guests have felt that the hotels want their money but are not ready to supply them with the needed service of check cashing.

42 "Credit Card Changing the Way You Do Business," Lodging and Hospitality. July 1977 , p. 42 .

$$
43 \text { Ibid. p. } 43 .
$$


The check guarantee has resulted in diminishing this attitude toward the hotel.

Two of the most important problems faced by the lodging industry are no shows and over booking.

The credit card companies have come up with a plan which guarantees reservations.

This plan appears to partially answer a problem which has plagued the industry for the last two decades.

Each card company offers a slightly different program. But basically, an individual making a rvation agrees to guarantee and back up his reservation by giving his credit card number to the hotel.

The hotel, for its part, promises that should a traveler arrive with a credit card guaranteed reservation, and the hotel has no room to offer him, the hotel must find him an altemate room elsewhere at the guaranteed price; in addition they must provide him transportation to the new location and pay for one phone call so the guest may advise home or office of the change in his accommodation.

By the same token, if the traveler fails to arrive and has not properly cancelled his reservstion, the credit card company will pay the price of one night's lodging to the hotel operation. The card companies pay whether the traveler eventually settles his account with them or not. Some hotels may give the guest the opportunity to cancel their reservation by $6 \mathrm{p} . \mathrm{m}$, the day of the reservation, in 
order to avoid being billed. 44

W1Ilam Fowler, Vice President of Beservations for Holiday Inn, claims that today about 80 percent of the no shows pay with no questions asked, compared to the one percent collection rate for no shows with guaranteed reservations, before the credit card guaranteed reservation system was instituted. Mr. Fowler states that:

The Guaranteed Reservation Program is now working so well that we receive only seven complaint $5_{45}$ out of every 10,000 bookings. 45

American Express claims that the reservation system has saved a lot of money for the hotels. In $1980 \$ 24$ milion dollars were protected from becoming losses arising from no shows. 46

The Guaranteed Reservations System has become so important that Larry Walker, Director of Room Operations for the Sheraton Corporation, predicts that within the next two years the only way anyone will be able to make hotel/motel reservation w111 be via credit card or an advanced deposit. 47

The credit card quaranteed reservation might prevent an expected povernment intervention to limit overbooking in hotels.

44 Ibid., p. 44.

45 "Coming-A Sure Way to Eliminate No Shows and Overbooking," Motel/Hotel Insider Newslezier, Dec. 3, 1979, p. 2. 46 "Amex Launches Largest Media Campaign on Behalf of Lodging Industry," Hotel/Motel Insider Newsletter, May 19, 1980, p.3. 47 Coming-a Sure Way to Eliminate No Shows and Overbooking, "op cit., p. 2 . 
In contrast to the past when the responsibility was placed only on hotels, today the responsibility falls upon both the hotel and the guests to solve the problem of no shows.

Another advantage of the credit card guaranteed reservations is that the guests who make use of the service are registered prior to their arrival at the hotel and are able to check out without going through a cashier (there is no need to sign the credit card). This eliminates the necessity of standing in line and creates more satisfied customers. 48

Research has discovered that credit card holders, and especially the travel and entertainemtn card holders who frequently and repeatedly use hotels, are bigger spenders that other cash paying customers.

As Marvin Price, Diner's Club Senior Vice President of Sales said:

The innkeeper can
expect to make more
profit per sale on the
typical travel and
entertainment card
holder. They will take
a better room, a larger
sulte; he will spend
more on food and bev
erates while staylng in
the hotel and his very
seldom listed as a no show. 49

48"A mex Launches Largest Media Campaign on Behalf of Lodging Industry," Hotel/Motel Insider Newsletter, May 1980, p.3. 49"Diner's Club Moves to Increase Its Share of Travel and Entertainment Market," Hotel/Motel Insider News letter, July 23, 1979, p. 1. 
Besearch done by Lodging and Hospitality Magazine found that bank cards are mostly used for pleasure travel While the travel and entertainment cards apparently get the Iion's share of business people. Resort properties, for example, report frequent use of bank ards. 50

The following are Laventhol and Horwath's findings concerning the use of credit cards in hotels:

- At hotels in Center city credit card sales were 50.6 percent of total sales.

- At airport hotels credit card sales were 42.6 percent of total sales.

- At suburban hotels credit card sales were 48.9 percent of total sales.

- At highway hotels credit card sales were 48.2 percent of total sales.

- At resort hotels credit card sales were 32.2 percent of total sales. 51

These findings show a large portion of hotel sales are being funded by credit card charges. The higher the hotel occupancy and room rete--usually hotels at the center of the city--the higher the use of credit cards in relation to total sales.

When credit card sales are so high in proportion to total sales and the money is being delayed by the card companies (travel and entertainment) there might be a resultant problem with the hotel cash flow. This is impor-

50"Credit Card: Changing the Way You Do Business," Lodging Industry, JuIy 1977, p. 42 .

5l Leventhol and Horwath, U.S. Lodging Industry, 1982 , p. 60. 
tant in regards to the money needed for every day operation. The Laventhol and Horwath study indicates that the ratio of credit card commission to total gales is as follows:

- Hotels in center city locations - 1.3 percent of total sales.

- Hotels in airport areas -1.3 percent of total sales.

- Hotels in suburban areas - 1.3 percent of total sales.

- Hotels alongside highway - 1.2 percent of total sales.

- Resort hotels - 1.3 percent of total sales. 52

These percentages when compared to a U.S. hotel's average net income of $7-15$ percent of total sales, show that credit cand service commissions can be a very meaningful amount of money, taken away from hotel's net earning. These fees lower hotels net income which is already low, compared to the net income of other industries.

Eliminating the acceptance of credit cards in hotels might increase slightly the hotel's net income; but it might also create problems which were mentioned before and were solved by the credit card phenomenon.

Or, as a Lodging Hospitality magazine states:

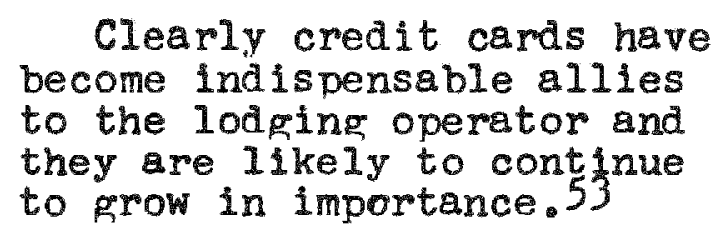

52 Ibid. p. 6.

53 "Credit Card-Changing the Way You Do Business," Lodging Hospitality, July 1977, p. 44. 
Restaurant and Credit Cards

Restaurants are closely associated with credit cards.

Usually, the higher the restaurant menu prices the more likely it acoepts payment by credit cards.

It follows that fast food establishments don't

accept them because they work on high volume sales, fueled by low tickets and rapid customer turnover.

Coffee shops and family restaurants usually don't accept plastic money either, but there are some exceptions such as Denny's, that accept credit cards in restaurants that have cocktail lounges.

Family restaurants and coffee shops which are located near hotels and motels, or in an area that servas large numbers of travelers tend to honor charge cards, especially travel and entertainment cards, in an effort to attract more business and build a higher ticket base for their operations. Traditional white table cloth restaurants are the major establishments that honor credit cards. 54 Many restaurant owners voice objections to the 1 dea of the use of credit cards at their establishment and their reasons why. George Valian, an owner of a white tablecloth restaurant in Houston, voices opposition:

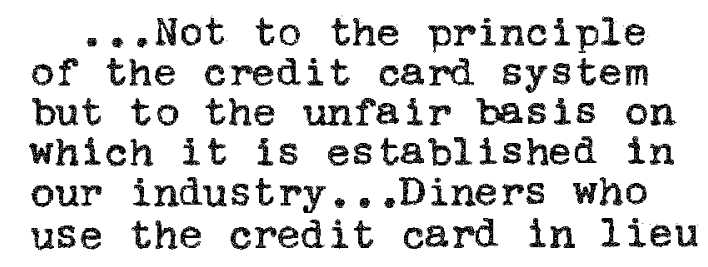

54"Cash Versus Credit: The Bargain Battle in Credit Cards," Bestaurant Business, p. 80 . 


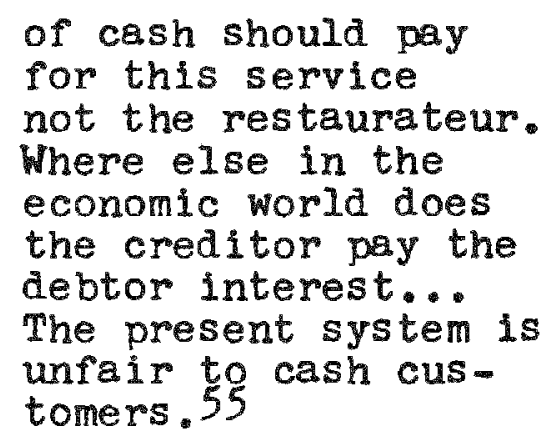

other restaurateurs complain about being caught between high food costs and charge card fees. They complain especially about the high charges and slow payment of the travel and entertainment credit cards.

Atlanta restaurateur Bruce Bozzi, owner of the Palm in New York, claims to have thought about dropping the travel and entertainment cards:

\footnotetext{
"But we haven't had the guts to do it yet.... If American Express fees w111 be raised I'II probably suggest that custgmers use the other cards. 56
}

Other restaurateurs 1 ike Jim Demerouts from Toronto views the credit card issues differently:

"It's a way of life
today; sure, you pay a
fee, but what they fall
to reallze is that a lot
of business is there be-
cause they are serving
credit cards. I don't
think that people should

55 Ibid. p. 80. p. 1. 56"Top Restaurant," Wal1 street Journal, August 6, 1981 , 


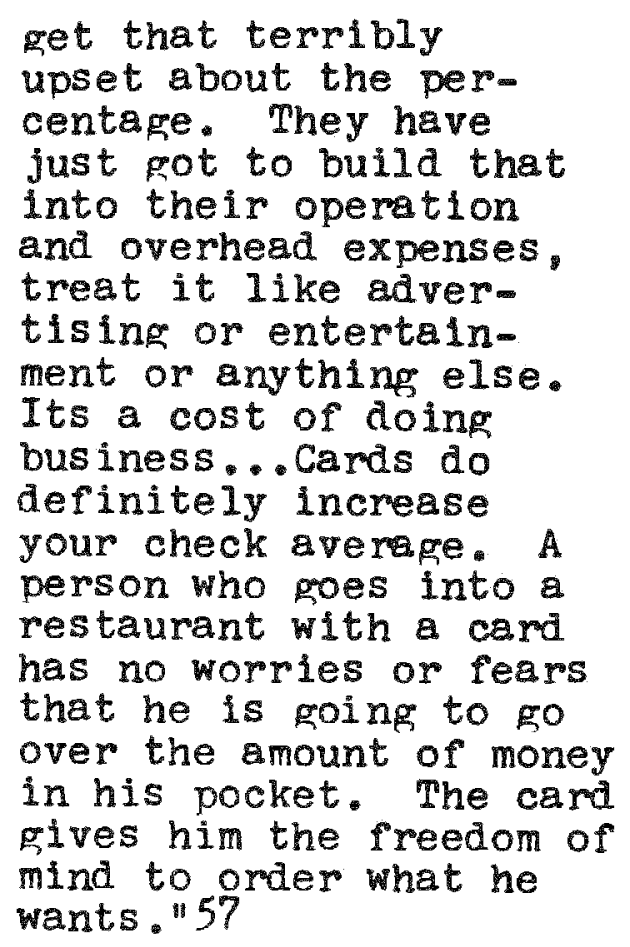

Another positive position is taken by Nick Sacharewick, owner of Sir Nicholas in Toronto, where a meal with wine averages 15 dollars. "I know that even with the low ticket level, people are spending much better and freer with the cards. "58

A study done by the National Restaurant Association In 1974 has shown that:

- The use of credit cards to pay for meals increased with income level.

- Credit card usage is highest in the 35-44 years old segment.

- Use of credit cards is also highest among better educated respondents. 59

57 "Credit Cards... and What They Can Do for Your Business," Canadian Hotel \& Restaurant, June 1975, p. 37.

58 Ibid. p. 37. 59 "Cash Versus Credit: The Bargain Battle in Credit Cards,"
Restaurant Business, January 1976 . p. 80 . 
These findings can support the claims of the major card companies that credit card users usually spend more, are more highly edueated, and earn more money than customers that don't pay with credit cards.

The difference in the amount of discount rates charged by the bank cards and the travel and entertainment cards, and the time it takes the money to be delivered to the restaurant is so big that one of the executives of a large restaurant chain notes in a Restaurant Business magazine interview that his chain of specialty restaurants follow a policy of only accepting bank credit cards due to the differences mentioned above. 60

The travel and entertainment companies are aware of the disadvantage they represent to narrow profit oriented businesses like the food industry. They argue that the travel and entertainment card members are more affluent and thus, more prone to eat out. When they patronize restaurants they spend more than either bank card or cash paying customers.

A Carte Blanche executive notes:

Our surveys show that most men use a travel and entertainment card to pay for thelr travel and entertainment expenses including dining out while they have bank cards at home for their wives to use in their local shopping. 61

60 Ibid., p. 82. ${ }^{61}$ Ibid., p. 84. 
According to American Express, the leading travel and entertainment card issuer, its cardholders eat in restaurants an average of four and a half times in a two week period.

This is twice the average for bank card holders and three times that for cash customers.

Business meals, which account for two thirds of the meals eaten out by American Express card members, are three times more frequent among this group than bank card holders, and six times greater than those who pay with cash. 62

It seems that restaurant operators are aware of both the advantages and disadvantages of the credit card and most of them have chosen to give the customer the option to charge his meal.

A spokesman for Longchamp Steak and Brew chain claims:

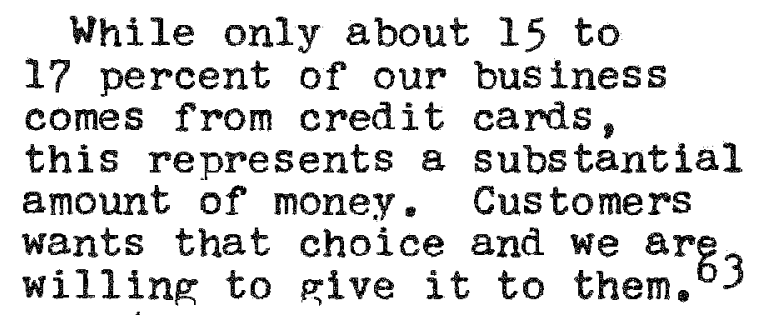

Unt11 1974, cash discounts were prohibited by the card companies. But the Credit Billing Act of 1974 allowed the restaurants to offer 5 percent discounts for cash paying customers.

It seems that the trend to attract customers to pay cash by using the cash discount is not favored by most res-

$$
62 \text { Ibid., p. } 84 \text {. }
$$

63"Plastic Money Here to Stay," Restaurant Business, September 1974, p. 172 . 
taurateurs.

Restaurant Business magazine has found that most of the restaurants that were interviewed did not use the cash discount.

Some, like a major chain executive, proposed instead add Ing a premium of one to three percent on the customer guest check if he pays by credit card.

This extra charge was forbidden by the Federal Reserve Board, which ruled that any amount added to posted charges w11 be considered a financial charge.

Another restaurant executive suggested that restaurants that accept credit cards should establish a minimum check average so that the higher tickets he collects would compensate for the discount rate he pays. 64

It seems that still many restaurants are debating whether or not they should accept credit cards.

Restaurant Business magazine claims that chances are that if your average check is high enough, a substantial percentage (12-50 percent) of your customers wi11 wish to pay with credit.

"You may not lose long time customers by insisting on cash, but you won't win friends and influence card holders elther. $" 65$

A similar view, more aggressive and more financially

64"Cash Versus Cred1t: The Bargain Battle in Credit Cards," Restaurant Business, January 1976, p. 82.

65 "Plastic Money Here to Stay, "Restaurant Business, September 1974, p. 203. 
orlented is heard by Robert $T$. Patterson, a partner in Laventhol and Horwath.

In his article in Food Service Marketing Magazine, Mr. Patterson claims that in a restaurant with one miliion dollars sales, 35 percent of sale or $\$ 350,000$ dollars are credit card charges. (Based on the findings that in California 35 percent of total dinner house revenues are credit card sales). The average fee paid to the credit card companies is. $\$ 13,125$ dollars, or 3.35 percent of each dollar of credit card sales.

The operators belief, typically, is that if he stopped accepting credit cards he would add more than $\$ 13,000$ dollars to his profit. He assumes, however, that all his customers who used credit cards would then pay cash or that his restaurant is so busy that other cash paying customers would replace dispruntled credit card users. If neither event happens, the 13,125 dollars savings will be lost.

Mr. Patterson indicates that the true variable cost associated with $\$ 1.00$ dollar of sales in a dinner house is usually around sixty cents.

This figure is arrived at as follows: (See following, page). 


\section{Variable Cost Per}

Dollar of Sale

Cost of Sales

$\begin{array}{r}\$ \quad 0.36 \\ 0.10 \\ 0.05 \\ 0.06 \\ 0.03 \\ \hline \$ \quad 0.60\end{array}$

Variable Portion of Labor

Direct Operating Expenses

Percentage Rent

.06

Variable Portion of All other

Total Variable

The loss profit in this case is forty cents for each dollar.

The sales which would have to decline in order to completely negate the $\$ 13,125$ dollars savings are:

$$
\frac{\$ 13,125}{0.40}=\$ 32,812 \quad \begin{aligned}
& \text { (Sales decline which } \\
& \text { would offet credit } \\
& \text { card savings) }
\end{aligned}
$$

Thus, if sales decline more than 3.3 percent, the restaurant profit will decline.

In the example, 3.3 percent is less than 10 percent of card holder sales.

Thus, if one credit card user in ten takes his business elsewhere, the restaurant will lose money.

Chances are that a considerable portion of the credit card sales coming from business people will be lost, because credit card receipts and bills are an excellent expense report record; business people generally prefer to use credit cards. 
Generally, a business meal for three or four people w111 cost more than the host or hostess has on hand. If there is a choice between two good restaurants, one of which accepts credit cards and one which doesn't, the former will more 11 kely be chosen.

In addition, there are likely to be diners who do not carry large amounts of cash and would be embarrassed if informed at the end of a meal that the restaurant no longer honors credit cards. Being embarrassed in an establishment almost certainly will discourage further patronage.

When a restaurant doesn't accept credit cards there is a pressure to establish a house charge. Basically, it is the operator's own account receivable function. In general, operators are not well enough organized to handle such a responsibility. Losses from bad debt and poor bookkeeping often prove to be high. 66

The advantages and disadvantages of the credit card have put restaurateurs in a Catch-22 situation. Accepting credit cards may prove to be an unwelcome expense, but not accepting them may result in losing a significant number of customers. The resarcher after gathering the necessary data hopes to be able to offer alternative uses to credit that maximize the advantages and minimize the disadvantages.

66 Robert Patterson, "Understanding Credit Card Business Who Do You Gain...Or Lose?" Food Service Marketing, June 1981, pp. $44-45$. 
SECTION III

THE DATA AND THE TREATMENT OF THE DATA 
THE DATA

\section{AND THE TREATMENT OF THE DATA}

The Data

The data of this research is of one kind, primary data. The nature of this type of data is given below.

The primary data. The primary data wi11 consist of responses to questions addressed to restaurant operators at Miami Beach.

The Criteria for the Admissibility of the Data

Only the responses to the questionnaire designed and administered by the researcher of this study will be used.

The Research Methodology

Leedy describes the descriptive method as:

$$
\begin{aligned}
& \text { The method of research } \\
& \text { that simply looks with in- } \\
& \text { tense accuracy at the } \\
& \text { phenomena of the moment and } \\
& \text { then describes precisely } \\
& \text { what the researcher sees. } \\
& \text { In other words the descrip- } \\
& \text { tive survey is the method } \\
& \text { employed to process the } \\
& \text { data that comes to the } \\
& \text { researcher through observa- } \\
& \text { tion. }
\end{aligned}
$$

This researoh was the descriptive survey within this definition.

Specific Treatment of the Data for Each Subproblem

Subproblem one. The first subproblem is to determine

67 Paul D. Leedy, Practical Research (MacMilian Publishing Co. Inc.. 1980): p. 97" 
the attitude of restaurant operators toward the use of credit cards at their establishment.

The Data Needed

The data needed for the solving of subproblem one are the restaurant operators responses to the questions asked of them regarding their positive or negative opinion toward the use of credit cards at their establishment.

The Location of the Data

The data are located in the response of restaurant operators in Miami Beach.

The Means of Obtaining the Data

The response will be obtained by personally interviewing the restaurant operators. The interviews will be prearranged by a telephone request.

The Treatment of the Data

A simple tallying of those in favor or against the use of credit cards will show where the majority lies.

Subproblem two. The second subproblem is to analyze operators attitude toward the use of credit cards at their esteblishment.

The Data Needed

The data needed are operators response regarding negative or positive effect of the use of credit cards for their establishment. 
The Location of the Data

The data are located in the responses of restaurant operators in Miami Beach.

The Means of Obtaining the Data

The data will be obtained by personal interviews with restaurant operators in Miami Beach.

The Treatment of the Data

The interview responses will be analyzed in order to understand restaurant operators reasoning for their attitude. If needed, a solution to the current situation will be suggested based on the researcher's analysis of the operators responses. 
SECTION IV

THE SURVEY BACKGROUND 


\section{THE SURVEY BACKGROUND}

The purpose of the study was threefold:

1. To determine restaurant operators attitudes towards the use of credit cards at their restaurants.

2. To find out the reasons for their attitudes.

3. To determine a method that will help them solve the problems of credit card usage, if a problem is, in fact, discovered.

The population Iist from which the sample restaurants were drawn was compiled by going through the restaurant section of the Miami telephone book's yellow papes and extracting all restaurants located within the physical boundaries of Miami Beach.

This list was then cross referenced with the restaurants Iisted in the Licensing Department at the Miami Beach City Hal1. Together this produced a list of 295 restaurants. From this list 73 restaurants were found to have more than 100 seats.

of those restaurants that were contacted, approximately 55 percent were eliminated from the study because they did not meet one of the two criteria for admissibility; either they were not free standing operations or they did not accept both types of credit cards (bank cards and travel and entertainment cards). The resulting popu- 
lation of this study was 33 restaurants.

The primary difficulty faced by the researcher in obtaining the sample was getting through to the restaurant operators without knowing their names. often times a maitre' d or the waiter answering the telephone refused to assist the researcher in making contact.

When contact was made, most operators objected to the financial nature of some questions and consequently would not answer them.

In these cases, aditional questions were asked in such a way as to obtain the closest answer without the operator feeling as though he had divulged confidential information.

Assuring the operators anonymity and of the fact that the survey was not directed toward assessing their financial position were other measures taken which encouraged operators participation.

At the end of fourteen days survey period, a total of 17 completed surveys had been obtained.

The final selection process became one of opportunity, but it is the belief of the researcher that it can logically be concluded that the sample is adequate in size and representativeness to meet the needs of the study. It should be noted that most of the personal interviews with the operators were prearranged by telephone calls. Three operators preferred to answer the questions on the telephone, and were obliged. 
Some of the questions were desipned for yes or no answers, and some offered other alternatives.

One question was designed to give the operator an opportunity to explain in their own words their reasons for their answer to the previous question.

In order to assure the effectiveness of the questionnaire design, the opinion of a fellow student in the School of Business at Florida International University and a restaurant operator were sought. One revision was made and the survey was then pretested on two respondents. 
SECTION V

SURVEY QUESTIONS AND ANSWERS 


\section{SURVFY QUESTIONS AND ANSWERS}

1. What kind of credit cards do you accept at your restaurant?

$\begin{array}{lc}\text { Master card } & 100 \% \\ \text { VISA } & 100 \% \\ \text { American Express } & 88.2 \% \\ \text { Diner's Club } & 58.8 \% \\ \text { Carte Blanche } & 58.8 \%\end{array}$

2. What is the discount rate charged to your restaurant by VISA or Master card?

$$
\begin{aligned}
& 2-3 \text { percents } \quad-\quad 47.1 \% \\
& 3-4 \text { percents } \quad-\quad 52.9 \%
\end{aligned}
$$

3. What is the discount rate charped to your restaurant by American Express, Diner's Club or Carte Blanche?

$$
\begin{array}{ll}
4-5 \text { percents } & 29.5 \% \\
5-6 \text { percents } & 41.0 \% \\
6-7 \text { percents } & 29.5 \%
\end{array}
$$

4. How Iong does it take for American Express, Diner's club or Carte Blanche to reimburse you for your credit card customer charpes?

\begin{tabular}{|c|c|}
\hline No & - \\
\hline Yes & - \\
\hline
\end{tabular}

$$
\begin{array}{cc}
5 \text { days } & 11.8 \% \\
6 \text { days } & 23.5 \% \\
7 \text { days } & 23.5 \% \\
8-12 \text { days or more } & 41.1 \%
\end{array}
$$

5. Do you think that your every day operation is being hurt because of the period of time it takes you to collect your money from the credit card companies? 
6. If yes, in what way?

Need for the money to pay employees, pay for supplies and other daily operating expenses:

$$
61.5 \%
$$

No comment

$$
38.5 \%
$$

7. of your total sales, what percentage are credit card sales?

Twenty-five percent of total sales $35.3 \%$

Thirty-five percent of total sales $11.8 \%$

Forty-five percent of total sales $11.8 \%$

No answer

$41.1 \%$

8. Do you think that credit cards ... (check all applicable answers ):

- Bring more clients

$41.1 \%$

- Increase your sales

$23.5 \%$

- Decrease your profit

$76.5 \%$

- Have a negative effect

$70.5 \%$ on your cash flow

- Cause extra paper work

$66.6 \%$

- Present problems of forgery

$11.7 \%$

9. Do you consider the acceptance of credit cards at your restaurant a burden to your operation?

$\begin{array}{ll}\text { Yes } & 58.8 \% \\ \text { No } & 23.5 \%\end{array}$

No Answers

$17.7 \%$

10. Would you consider employing measures to encourage your customers to pay cash?

$\begin{array}{ll}\text { Yes } & 46.15 \% \\ \text { No } & 15.40 \%\end{array}$


11. Would you consider:

- Giving cash discounts for cash paying customers

- Offering complimentary drinks to cash paying customers

- Joining a bank plan that offers cash paying customers a discount

- Doing nothing 
SECTION VI

THE INTERPRETATION OF THE SURVEY FINDINGS A IND

RECOMMENDA TION 
THE INTERPRETATION OF THE SURVEY FINDINGS AND RECOMMENDATIONS

The first hypothesis is that restaurant operators don't like the use of credit cards at their establishments, especially the travel and entertainment credit cards. Questions number five and nine, which try to evaluate the operators attitudes, indicate that most operators don't like the use of credit cards at their establishment.

Of the operators questioned, $76.5 \%$ thought that their restaurants are being hurt because of the time it takes them to collect the money from the travel and entertainment credit card companies.

The researcher observed that the longer it takes the restaurant operator to collect his money, the more alienated the operator becomes, and the more negative his attitude.

Of the operators questioned, $58.8 \%$ considered the acceptance of credit cards at their restaurant as burdens, while $17.7 \%$ did not answer the question.

The researcher presumes that the majority of those that chose not to answer also feel negative about the use of credit cards in their restaurents.

When restaurant operators need for cash flow cause him to be concerned with the period of time it takes to be reimbursed by the card company, his attitude toward 
credit use becomes more negative. But the lower percentage of unsatisfied operators indicated in question number 9 can be contributed to the fact that the bank cards are reimbursing the money the next day it was deposited to the bank, and that seemingly decreased the operators dissatisfaction.

It is important to note that the survey was done in January, which is the busy season for Miami Beach res. taurants.

When restaurants are busy their food and beverage inventory turnover is high, and their number of employees increase; other expenses also increase, and a higher cash flow is needed for every day operations.

The second hypothes is is that restaurant operators don't like the use of credit cards because of the negative effect on their business cash flow and profits.

The answers to question number 8 supports the second hypothesis. of the operators questioned, $76.5 \%$ claimed that credit cards decrease their profit, and $70.5 \%$ see the credit card as having a negative effect on their cash flow.

When asked in question number 6 , how it effects them, the researcher learned that there is a big need for cash in the every day operations of these restaurants. of the operators interviewed, $61.5 \%$ claimed the money was badly needed to pay for food and beverage payroll and 
other expenses.

The high percentage of credit cards sales to total sales $(25 \%, 35 \%, 45 \%)$ means a decreased cash flow which can result in a financial burden to the operators.

The researcher noticed that the operators attitudes became more nepative when the portion of credit cards sales to total sales was higher, and the period of collection was longer.

of the operators questioned, $41.1 \%$ stated it takes the travel and entertainment card companies eight to twelve days to reimburse their money, and some claimed that sometimes it takes even more.

The effect of the "missing money" is felt by the operators.

When questioned, $41.1 \%$ of the restaurant operators stated that the acceptance of credit cards increase their clientele, but only $23.5 \%$ claim that it increases their sales.

It seems that the popularity held negative attitudes of the operators toward credit cards causes them to see only some of the results of accepting credit cards. They are aware of the decrease in their profits, due to the high discount rates charper them by the credit card companies. The percent of operators who claimed that the credit cards decreased their profits was $76.5 \%$; while only $23.5 \%$ claimed that the acceptance of credit cards 
causes their sales to increase.

A careful look at these answers show that $23.5 \%$ of the operators are satisfied with the acceptance of credit cards. They see it as no danger to their operation. These operators accept the extra oost of the credit cards as an overhead expense and do not consider the length of reimbursement time as that much of an inconvenience.

Based on informal talks with the satisfied operators it appears that their operations are geared toward the idea of increasing sales and profits by serving more customers. They realize (maybe what the other do not) that the cost of credit cards w111 decline, as credit cards bring them more clients.

Even though most of the operators realize the increase in sales due to the acceptance of credit cards, the decrease in profits brought on by the discount rate causes their overal1 attitude to be negative.

Another major claim which was made by $66.6 \%$ of the operators is that the credit cand caused them extra paper work. Operatine a restaurant is a very demanding and time consuming business, and the operetors peel that the time they or their employees have to put into the credit card paper work costs them time and money, which are scarce anyway.

One of the credit card problems that face merchants is the inevitable mistaken acceptance of some forged or 
unauthorized cards.

The survey shows that this was not seen as a major problem for the majority of surveyed operators; only 11.7\% brought up this claim and this is an insignificant percentage.

Although most of the operators have no problem with forged credit cards, some of them mentioned being inconvenienced by the time it takes to obtain authorization for the amount of the charre.

Although the vast number of the operators were negative in their feelings towards the use of credit cards at their restaurants, they accept credit cards none the less, and do not intend to cancel their acceptance.

With all the resentment towards the credit card, the operators still appear to realize that because of the high percentage of credit card sales to total sales. canceling the acceptance of credit cards might have a worse effect on their business and overall profit.

Most of the operators showed negative attitudes toward the credit cards and preferred cash sales, although no real action was taken to encourage credit card paying customers to nay with cash.

Of the operators questioned, $46.15 \%$ like the idea of encouraging customers to pay cash; $15.4 \%$ objected to the idea and $38.45 \%$ hadn't given much thought to the idea until they were asked by the researcher. 
The number of operators interested in offering substitutes to the use of credit cards without canceling their acceptance grew when the operators were informed of practical ideas.

of the operators interviewed, $36.4 \%$ stated they would consider offering cash discounts for cash paying customers. In fact, most of this $36.4 \%$ would not only consider it, but were enthusiastic about the idea. Others have mentioned that they have heard about these discounts but as yet were not willing to try them.

None of the operators were willing to offer complimentary drinks to cash paying customers. They claim that the only people that will enjoy it are the customers who intend to pay with cash anyway. The believe that this benefit would not induce the credit card customers to pay cash, and the restaurants will be the ones to lose.

A very high percentage of the operators (81.8\%) were enthusiastic about the possibility of joining a bank plan such as Saving Plus, once the idea had been explained to them.

Still, it was discovered that restaurant operators who do not like the use of credit cards because of the reasons previously mentioned, are doing nothing to try and eliminate any of the problems. Keeping up with every day operations and realizing that credit card usage is a way of Iife today, are two reasons that the operators 
are not addressing the problem.

The high percentage of operators who were enthusiastic about the bank cash discount plan indicates that they are likely to listen to, and cooperate with, anyone who offers a solution.

In the researcher's opinion, in order to encourage customers to use cash instead of credit cards, there should be a plan created which will involve banks, hotels, and restaurants.

The restaurants in Miami Beach are locked in a very special situation. Miami Beach is a residential area as well as a tourist cestination.

The Savings PIus program, which works on cooperation between the banks and restaurants, might not be well suited to Miami Beach alone.

A high percentage of patrons don't reside in the area and the short period of time that tourists are in Miami Beach does not favor their opening any type of bank account.

The future progrem should try to accommodate both residents and tourists, and therefore, makes cooperation between the bank, hotels, and restaurants vital.

The plan can include broader segments of businesses on Miami Beach in order to be more popular, or accepted, with the different clientele.

The basic idea of Savings Plus is to encourage resident customers to open a savings account with the 
sponsoring bank. The bank will sell and market the idea to the community.

The restaurants will charge the customers a full price for their meal, but a portion of the payment will be deducted by the restaurant operator and deposited into the customer's saving account. This will give the restaurant the advantages of having the money immediately and being able to hold on to the deposit for up to a month before depositing it in the customer's account.

When dealing with tourists another dimension is needed, and that is the hotels as the branch to market and sell the idea. Traveling puests are accustomed to using their credit cands wherever they stay.

The opportunity to get a discount by using a coupon that will be available for sale at their hotel, together with a list of recommended restaurants, will encourage the tourists to buy the coupon and use it as part of their payment. Tourists usually seek the recommendations of interestinf, places, including restaurants.

A coupon with restaurant names that offer a discount will encourage them to patronize the places. When the guest is entitled to a cash discount he will make a partial payment with the coupon and the remainder will be made in cash.

The hotels will deliver the money from the coupon sales, less their commission, to the bank. The bank will, 
in turn, deliver the money for the coupon to the restaurant at the time of the coupon deposit by the restaurant. For their involvement, the banks will profit by securing the accounts of the participating restaurants.

The plan will enhance the cash supply of the restaurants and will attract more customers because of the marketing done by the banks and the hotels. A large number of clientele will come because of the discount rate and this volume will make up for the discount rate and the commission.

The same argument cannot be used in favor of the credit cards because some of its holders will come to a particular restaurant even if credit cards aren't accepted. The "discount customers" are coming mostly because of the plan.

In conclusion, it is important to note that in order to get this plan working the involved restaurants should organize and work in cooperation with the bank and hotels in the area.

This plan can result in less credit card usage in the restaurants, an improved cash flow, and higher profits in the long run. 
SECTION VII

CONCLUSION 
In view of these findings the researcher concludes that restaurant operators in Miami Beach do not like the use of credit cards at their restaurants.

Further, the restaurant operators do not like it because of the negative effect on the restaurant's cash flow, the reduction of profits and the excess paper work credit card usage causes. In considering hypothesis two the researcher has found that the operators are not doing anything to prevent these negative effects. Their reasoning being that they are too busy with every day operation and do not think they can do anything to change the present system.

The obvious solution cancelling the acceptance of credit cards at their restaurants is unheard of. Although they express negative feeling toward the credit cards. Minimizing the credit card advantages and maximizing its disadvantages they realize the overall importance of accepting credit cards in their restaurants. They are aware to the customers that wouldn't have come unless being given the opportunity to pay by credit card, and by that decreasing the existing level of sales for their restaurant.

They know from others and their own experience that credit card customers are bigger spenders than cash customers and they would like to have more bigger spenders coming to their restaurant. Regardless the method of payment they are using.

The operators are willing to get along with the negative results of the credit cards acceptance and their own negative feelings as long as they realize that credit cards bring more customers to the restaurants while not accepting credit cards will decline the sales at their establishment.

The solution to the credit card problem will not be cancelling their acceptance but a cohesive program between banks, hotels and the invol ved restaurants designed to encourage customers to pay by cash while still accepting credit cards at these restaurants. 
The problem stands a chance of being solved only if the people who see it as a problem take the initiative to solve it. 
SECTION VIII

THE QUALIFICATIONS OF THE RESEARCHER 


\section{THE QUALIEICATIONS OF THE RESEARCHER}

Yair Eldar was borm in Tel Aviv, Israel, on May 23. 1955, and lived there until 1979 when he came to study in the Unfted States. While in Israel he received a Bachelor of Arts in Political Science in Tel Aviv University.

His work experience includes several years in the restaurant industry, jobs as a pollce officer in Tel Aviv, and as a security guard both in Tel Aviv and in New York for the Israeli Consulate.

In December 1981 he began studies in the School of Hospitality at Florida Intemational University in Miami. Florida. He will complete the requirements for his Masters of Science in Hospitality Management in Apri1 of 1984.

Since undertaking this project, Mr. Eldar has been employed as a front desk clerk at a Miami property owned by a major national hotel corporation. In February of 1984 he w111 begin a management training program with Radisson hotels. 
SECTION IX

BIBLIOGRA PHY 
SELECTED BIBLIOGRAPHY

\section{BOOKS}

Davis, Rich Dewey and Joseph G. Martin. Banking and Credit. New York: Arno Press, A New York TImes Compeny, 1980.

Galanoy, Terry. Charge It: Inside the credit card ConSpiracy. New York: G. P. Pulmanis Son, 1980.

Hendricks on, Robert A. The Cashless Society. New York: Mead \& Company, 1972.

Homer, Sidney. A History of Interest Rates. New Brunswick, New Jersey: Rutgers University Press, 1971.

Mande11, Lewis. Credit Card Use in the United States. Michigan. Braun \& Brumfield, Ann Arbor, Michigan, 1972.

Redding, Harold T. and Knight $\mathrm{H}$. Guyon. The Dun \& Bradstreet Handbook of Credit and Collection. New York: Thomas $Y$. Crowell Company, 1974.

Rist, Charles. A History of Money and Credit Theory from John Labu to the Present. New York: Augustus M. Kelley, 1966.

Busse11, Thomas. The Economics of Bank Credit Cards. New York: Praper Co. 1975.

Seder, John W. Credit and Collection. New York: David McKay Company, Inc., 1977.

PERIODICALS

"ABA Calls Bank Credit Card Key to Less Check Future." Management Services, March-April 1968, pp. 6-7.

Abouchar, Roger J. and Nicholas E. Magnis. "Bank Credit Card Implication for the Future," Banker Monthly. January 1967, pp. 22-24.

"Amex Launches Largest Media Campaign on Behalf of Lodging Industry," Motel/Hotel Insider Newsletter, May 19, $1980, \mathrm{p} .3$.

"Bank Cards are a Special Case," Banking. March 1977, p. 46. 
"Bank Credit Card Plans: Many Problems but Vigorous Growth," Burrough Clearing House, January 1967, pp. 13-16.

"Bankers Reshuffle Their Credit Card," Business Week, December 7, 1968, pp. 53-58.

"Banks Credit Cards Setting the Scene for Future Pos," Saving \& Loan News, August 1979, pp. 96-97.

"Business Side of Credit Cards," Industry Week, April 5, 1971, pp. $28-32$.

"Cash Versus Credit: The Bargain Battle in Credit Cards," Restaurant Business, January 1976, p. 80 .

"Clash of the Credit Cards," Dun's Review, June 1978, pp. 94-95.

"Coming: A Sure Way to Eliminate No Shows and Over Booking," Motel/Hotel Insider Newsletter, December 3, 1979, p. 2.

"Credit Card and What They Can Do For Your Business," Canadian Hotel \& Restaurant, June 1975, p. 37.

"Credit Card Banking," Banker Monthly Magazine, November 15, 1966, pp. 31-33.

"Credit Card: A Booming Business," Economist, September 23, 1978, p. 126.

"Credit Card: Changing the Way You Do Business, Lodging Hospital1ty, July 1977, pp. 42-43.

"Credit Card: Hot Items In a Cool Economy," "Black Enterprise, September 1968 , p. 28.

"Credit Cards: Like Money They Are Here to Stay," Financial World, May 27, 1970, p. 14.

"Credit Card War Moves into High Gear," U.S. News \& World Beport, March 5, 1979, pp. 70-74.

"Diner's Club Moves to Increase its Share of Travel and Entertainment Market," Mote1/Hotel Insider Newsletter, July $23,1976, p, 1$.

"Few Discounts for Cash Seen Despite Ruling," Advertisine Age, Apri1 22, 1974, p. 2 .

"Here Come the Bank Cards," Forbes, February 15, 1969, pp. 39-40. Johnson, Bob. "VISA Installing Systems to Combat Fraud, Computer World, September ?, 1981, p. 19. 
Kleche1, Walter III. "Explosion in the Bank Card Cafeteria," Fortune, September 8, 1980, pp. 77-80.

Laventhol \& Horwath, Ed. U.S. Lodging Industry. Philadelphia: Laventhol \& Horwath Publ., 1982.

Lozowick. Amold H. "Compatible Bank Credit Cards," Banker Monthly Magazine, October 15, 1967, pp. 26-30.

"Master Card and VISA Air Their Differences in Friendly Fashion," ABA Banking Journal, November 1981, pp. 113-114.

"On Guard American Express," The Economist, September 26, 1981. pp. $68-69$.

Patterson, Robert. "Understanding Credit Card Business. What Do You Gain... or Lose?" Food Service Marketing, June 1981, pp. $44-45$.

"Plastic Cards for Everything," The Economist, September 15, 1979, p. 114 .

"Plestic Money Here to Stay," Restaurant Business, Septenber 1974, p. 203.

Relstad, Dale L. "Credit Card: Stepping Stones to the Checkless Society?" Computer and Automation, January 1976, pp. $26-27$.

Rosefsky, Robert C. "When the Credit Cards Take Over," Banking, Apri1 1970, pp. 38-40.

Ross, Irwin. "The Credit Card's Painful Coming of Age," Fortune October 1971, pp. 108-111.

"Souping Up Gas Credit Cards," Business Week, February 25, 1967. p. 66.

"VISA'S Vision of An All In One Card," Business Heek, October 11, 1982, p. 108.

"What Ever Happened to Discount for Cash?" Changing Times, May $1980, \mathrm{pp} .57-59$.

\section{NEWSPAPERS}

"Discount for Cash," Wa11 Street Journal, September 30, 1982. Stickler, Robert. "Banks Wrapping Their Customers in Colored plastic," Miami Herald, September 5, 1983.

"Top Restaurant," Wa11 Street Journal, August 6, 1981. 
SECTION $X$

A PPENDIX 


\section{SURVEY}

1. What kind of credit cards do you accept at your restaurant?

Master Card, VISA, American Express, Diner's Club, Carte Blanche.

2. What is the discount rate charged to your restaurant by VISA or Master Card?

$$
\begin{aligned}
& 2-3 \text { percent } \\
& 3-4 \text { percent }
\end{aligned}
$$

3. What is the discount rate charged to your restaurant by American Express, Diner's Club or Carte Blanche?

$$
\begin{aligned}
& \text { 4-5 percent } \\
& \text { 5-6 percent } \\
& \text { 6-7 percent }
\end{aligned}
$$

4. How long does it take for American Express, Diner's Club or Carte Blanche to reimburse you four your credit card customer charges?

$$
\begin{aligned}
& 5 \text { days } \\
& 6 \text { days } \\
& 7 \text { days } \\
& 8-12 \text { days or more }
\end{aligned}
$$

5. Do you think that your every day operation is being hurt because of the period of time it takes you to collect your money from the credit card companies?

No

$$
\text { Yes }
$$

6. If yes, in what way?

7. Of your total sales, what percentage are credit card sales?

Twenty-five percent of total sales 
Thirty-five percent of total sales

Forty-five percent of total sales

other

8. Do you think that credit cards.....(check all applicable answers)

-Bring more clients

-Increase your sales

-Decrease your profit

- Have a negative effect on your cash flow

-Cause extra paper work

-Present problems of forgery

9. Do you consider the acceptance of credit cards at your restaurant a burden to your operation?

Yes

No

10. Would you consider employing measures to encourage your customers to pay cash?

Yes

No

11. Would you consider:

-Giving cash discounts for cash paying customers

- Offering complimentary arinks to cash paying customers

-Joininf a bank plan taht offers cash paying customers a discount

-Doing nothing 